\title{
Correction to: Robotic surgery for thoracic surgery
}

\author{
Tim Sandhaus · Marion Durand · Thorben Möller · Jan-Hendrik Egberts · Matthias Steinert
}

Published online: 28 November 2021

(C) The Author(s) 2021

Erratum to:

Eur Surg 2020

https://doi.org/10.1007/s10353-020-00674-9

The article "Robotic surgery for thoracic surgery", written by Tim Sandhaus, Marion Durand, Thorben Möller, Jan-Hendrik Egberts and Matthias Steinert, was originally published Online First without Open Access. After publication in volume 53, issue 4, page 142-148 the author decided to opt for Open Choice and to make the article an Open Access publication. Therefore, the copyright of the article has been changed to (c) The Author(s) 2020 and the article is forthwith distributed under the terms of the Creative Commons Attribution 4.0 International License, which permits use, sharing, adaptation, distribution and reproduction in any medium or format, as long as you give appropriate credit to the original author(s) and the source, provide a link to the Creative Commons licence, and indicate if changes were made.

The online version of the original article can be found under https://doi.org/10.1007/s10353-020-00674-9

\section{T. Sandhaus}

Department of Cardiothoracic Surgery, Jena University Hospital, Jena, Germany

\section{Durand}

Department of Thoracic Surgery, Hôpital Privé d'Antony, Ramsay Générale de Santé, Antony, France

\section{T. Möller · J. Egberts}

Department for General, Visceral-, Thoracic-, Transplantation-, and Pediatric Surgery, University Hospital Schleswig Holstein, Kiel, Germany

Univ.-Prof. Dr. med. M. Steinert ( $₫)$

Department of Visceral, Transplant, Thoracic and Vascular Surgery, University Hospital of Leipzig, Leipzig, Germany Matthias.Steinert@medizin.uni-leipzig.de
The images or other third party material in this article are included in the article's Creative Commons licence, unless indicated otherwise in a credit line to the material. If material is not included in the article's Creative Commons licence and your intended use is not permitted by statutory regulation or exceeds the permitted use, you will need to obtain permission directly from the copyright holder.

To view a copy of this licence, visit http:// creativecommons.org/licenses/by/4.0/.

The original article has been corrected.

Funding Open Access funding enabled and organized by Projekt DEAL.

Open Access This article is licensed under a Creative Commons Attribution 4.0 International License, which permits use, sharing, adaptation, distribution and reproduction in any medium or format, as long as you give appropriate credit to the original author(s) and the source, provide a link to the Creative Commons licence, and indicate if changes were made. The images or other third party material in this article are included in the article's Creative Commons licence, unless indicated otherwise in a credit line to the material. If material is not included in the article's Creative Commons licence and your intended use is not permitted by statutory regulation or exceeds the permitted use, you will need to obtain permission directly from the copyright holder. To view a copy of this licence, visit http://creativecommons.org/licenses/by/4.0/. 